\title{
Struktur Komunitas Plankton di Selat Belat, Kabupaten Karimun, Provinsi Kepulauan Riau
}

\section{Plankton Community Structure in the Belat Strait, Karimun Regency, Riau Islands Province}

\section{Lani Puspita}

\author{
Program Studi Pendidikan Biologi, Fakultas Keguruan dan Ilmu Pendidikan, \\ Universitas Riau Kepulauan, Indosesia \\ Koresponden: lanipuspita@fkip.unrika.ac.id
}

\begin{abstract}
Abstrak
Penelitian ini bertujuan untuk mengetahui struktur komunitas fitoplankton dan zooplankton di perairan Pulau Belat, yang meliputi jumlah taxa, komposisi jenis, keanekaragaman jenis, keseragaman jenis, dan dominansi jenis. Plankton diambil di 3 lokasi di sebagian ruas Selat Belat. Pengambilan sample dilakukan 2 kali, yaitu 8 Januari 2018 dan 30 Januari 2019. Sampel yang diambil dianalisis di laboratorium Produktivitas Lingkungan Perairan IPB; analisis yang dilakukan mencakup identifikasi dan pencacahan; hasilnya kemudian diolah dengan menghitung Indeks Keanekaragaman Jenis (H'), Indeks Keseragaman Jenis (E), dan Indeks Dominansi Jenis (D). Berdasarkan hasil analisis didapatkan bahwa Indeks H, E, dan D dari sampel fitoplankton yang diambil pada 8 Januari 2018 secara berturut-turut berkisar antara: $1.05-1.91,0.54-0.68$, dan $0.26-0.42$; sedangkan untuk sampel zooplankton nilai indeks secara berturut-turut berkisar antara: $1.01-1.12,0.47-0.56$, dan 0.42 - 0.51. Dan nilai Indeks H, E, dan D dari sampel fitoplankton yang diambil pada 30 Januari 2019 secara berturut-turut berkisar antara: $1.50-2.13,0.46-0.67$, dan $0.22-0.47$; sedangkan untuk sampel zooplankton nilai indeks secara berturut-turut berkisar antara: $1.35-1.65,0.81-0.85$, dan $0.23-0.30$. Nilai Indeks $\mathrm{H}$ yang berkisar antara $1.01-2.13$ menunjukan bahwa kondisi perairan berada pada kondisi tercemar sedang, tercemar ringan, dan belum tercemar. Pada sampel 8 Januari 2018, fitoplankton didominasi oleh jenis-jenis dari kelas Bacillariophyceae; sedangkan zooplankton didominasi oleh jenis-jenis dari filum Protozoa. Pada sampel 30 Januari 2019, fitoplankton didominasi oleh jenis-jenis dari kelas Bacillariophyceae; sedangkan zooplankton didominasi oleh jenis-jenis dari filum Crustacea.
\end{abstract}

Kata kunci: Struktur Komunitas, Plankton, Selat Belat

\begin{abstract}
Abstact
This study aims to determine the structure of the phytoplankton and zooplankton communities in the Belat Strait, which includes the number of taxa, species composition, species diversity, species evenness, and species dominance. Plankton is taken in 3 locations in some parts of the Belat Strait. Sampling was carried out 2 times, namely January 82018 and January 30 2019. Samples taken were analyzed in the IPB Aquatic Environment Productivity laboratory; the analysis carried out includes identification and enumeration; the results are then processed by calculating the Species Diversity Index $\left(H^{\prime}\right)$, the Species Eveness Index $(E)$, and the Spesies Dominance Index $(D)$. Based on the results of the analysis it was found that the $H, E$, and $D$ indexes of phytoplankton samples taken on January 8, 2018 ranged between: 1.05 - 1.91, 0.54 - 0.68, and 0.26 - 0.42; whereas for zooplankton samples the index values ranged between: $1.01-1.12,0.47-0.56$, and $0.42-0.51$. And the $H, E$, and $D$ index values of phytoplankton samples taken on January 30, 2019 successively ranged between: $1.50-2.13,0.46-0.67$, and $0.22-0.47$; whereas for zooplankton samples the index values ranged between: 1.35 - 1.65, 0.81-0.85, and 0.23 - 0.30. Index $H$ values ranging from $1.01-2.13$ indicate that the condition of the waters is in a medium polluted, mildly polluted, and uncontaminated condition. In the sample of January 8 , 2018, phytoplankton were dominated by species from the Bacillariophyceae class; whereas zooplankton is dominated by species of the Protozoa phylum. In the sample 30 January 2019, phytoplankton were dominated by species from the Bacillariophyceae class; whereas zooplankton is dominated by species of the crustacean phylum.
\end{abstract}

Keywords: Community Structure, Plankton, Belat Strait 


\section{PENDAHULUAN}

Selat Belat Kabupaten Karimun merupakan perairan yang digunakan masyarakat setempat untuk mencari ikan; perairan ini juga merupakan perairan yang biasa dilalui kapal penumpang dari dan menuju Pulau Karimun Besar. Kualitas perairan Selat Belat diperkirakan dipengaruhi oleh kegiatan pelayaran dan tata guna lahan di Pulau Belat. Tata guna lahan di Pulau Belat saat ini berupa permukiman, perkebunan (terutaman karet dan palawija), dan bekas pertambangan bijih bauksit; di sisi pantainya juga dapat ditemukan hutan mangrove.

Kualitas suatu perairan antara lain dapat dilihat dari struktur komunitas planktonnya. Plankton merupakan mikroorganisme air yang hidup melayang mengikuti arus dan gerakan air. Plankton dapat dibedakan menjadi dua golongan yaitu fitoplankton dan zooplankton. Dalam ekosistem perairan, fitoplankton berperan seperti tumbuhan yang menentukan produktivitas perairan (Nybakken, 1992; Odum, 1998; dan Nontji, 2008). Fitoplankton dan zooplankton sering juga dipakai sebagai indikator biologis terhadap adanya perubahan kondisi lingkungan perairan, misalnya masuknya bahan-bahan pencemar ke dalam perairan yang dapat menimbulkan dampak negatif bagi keseimbangan ekosistem (Basmi, 2000 dan Fachrul, 2012). Nilai Indeks Keanekaragaman Jenis ( $\left.H^{\prime}\right)$ dapat dijadikan salah satu indikator pencemaran lingkungan. Menurut Lee et al., 1978 dalam Fachrul, 2012, perairan dengan Indeks H'> 2.0 menandakan perairan yang belum tercemar, nilai $1.6 \leq \mathrm{H}^{\prime}<2.0$ menandakan perairan yang tercemar ringan, dan nilai $1.0 \leq \mathrm{H}^{\prime}<1.6$ menandakan perairan yang tercemar sedang.

Parameter Keseragaman Jenis (E) dan Dominansi Jenis (D) adalah dua parameter struktur komunitas lain yang biasa dikaji. Indeks Keseragaman Jenis mengambarkan kondisi habitat relatif serasi (baik) untuk pertumbuhan dan perkembangan masing-masing spesies. Nilai Indeks Keseragaman jenis berkisar antara $0 \leq \mathrm{E}<0,3$ berarti keseragaman antar spesies di dalam komunitas adalah "rendah", mencerminkan keseragaman yang dimiliki masingmasing spesies sangat jauh berbeda. Bila nilai Indeks Keseragaman Jenis berkisar antara 0,3 $\leq$ $\mathrm{E}<0,6$ berarti keseragaman antar spesies di dalam komunitas "sedang", mencerminkan keseragaman yang dimiliki masing-masing tidak jauh berbeda, tidak menunjukan perbedaan yang sangat mencolok. Bila nilai Indeks Keseragaman Jenis berkisar antara 0,6 $\leq \mathrm{E} \leq 1$, maka keseragaman antar spesies dapat dikatakan relatif merata dan hal tersebut menunjukan kondisi yang baik ( Odum, 1998 dan Basmi 2000). 
Pada penelitian ini dilakukan pengambilan sample plankton di sebagian ruas Selat Belat; tepatnya di ruas selat yang berdekatan dengan permukiman penduduk Desa Sebele, hutan mangrove, dan muara Sungai Makam. Penelitian ini bertujuan untuk mengetahui struktur komunitas fitoplankton dan zooplankton di perairan Selat Belat, yang meliputi jumlah taxa, komposisi jenis, keanekaragaman jenis, keseragaman jenis, dan dominansi jenis. Hasil penelitian ini diharapkan dapat dijadikan informasi bermanfaat untuk mengambarkan kondisi lingkungan perairan di Selat Belat, karena plankton merupakan salah satu bioindikator yang dapat digunakan untuk mengetahui kondisi kesuburan dan pencemaran di suatu perairan.

\section{METODE PENELITIAN}

Pengambilan sampel plankton dilakukan di Selat Belat, Desa Sebele, Kecamatan Belat, Kabupaten Karimun. Pengambilan sampel dilakukan pada siang hari di tanggal 8 Januari 2018 dan 30 Januari 2019. Kondisi cuaca pada saat pengambilan sampel di kedua waktu tersebut adalah cerah. Identifikasi jenis fitoplankton dan zooplankton dilakukan di Laboratorium Produktivitas Lingkungan Perairan IPB. Dalam penelitian ini ditetapkan 3 stasiun sampling, yaitu: Stasiun 1 di dekat permukiman penduduk, pada koordinat: 048'36.78" N 103 $28^{\prime} 51.67$ 'E; Stasiun 2 di dekat hutan mangrove, pada koordinat: $0^{\circ} 48^{\prime} 55.32$ " N 103 28 '43.87'E; Stasiun 3 di depan Muara Sungai Makam, pada koordinat: 049'21.89” N 10328'19.87’'E.

Peralatan yang digunakan pada studi ini meliputi: plankton-net dengan mesh size 10 $\mu \mathrm{m}$, botol sampel plankton bervolume $10 \mathrm{ml}$, ember bervolume 10 liter, mikroskop, StripSRC (Sedwick Rafter Cell), pipet tetes, cool box, lemari pendingin, tissue, buku identifikasi (Yamaji, 1979), dan handy-counter. Sedangkan bahan yang digunakan pada studi ini adalah es, lugol 10\%, dan aquades.

Pengambilan sampel plankton dilakukan dengan menyaring 100 liter air laut menggunakan plankton-net. Pengambilan sampel dilakukan di permukaan perairan. Sampel plankton yang terkumpul pada botol sampel kemudian diawetkan dengan lugol $10 \%$ lalu disimpan di cool box. Sampel plankton yang telah diawetkan kemudian dibawa ke laboratorium untuk diidentifikasi dan dihitung kelimpahannya.

Analisis sampel fito dan zooplankton di laboratorium dilakukan dengan pengamatan di bawah mikroskop. Pengamatan di bawah mikroskop ini dilakukan untuk mengidentifikasi 
jenis fitoplankton dan zooplankton serta mengetahui jumlah individu masing-masing jenis fitoplankton dan zooplankton. Dengan mengetahui jenis dan jumlah individu masing-masing jenis, kita kemudian dapat menghitung kelimpahan fitoplankton dan zooplankton, komposisi jenis, keanekaragaman jenis, keseragamanan jenis, dan dominansi jenis. Pengamatan fitoplankton dan zooplankton dengan mikroskop dilakukan dengan tahapan berikut: (1) mengocok air sampel plankton dalam botol sampel agar homogen, dan (2) mengambil air sampel dari botol sampel dengan pipet tetes untuk kemudian diteteskan pada Strip-SRC. Perhitungan kelimpahan jenis fito dan zooplankton adalah sebagai berikut:

$$
N_{i}=\frac{n_{i}}{V_{o}} \times \frac{V_{r}}{V_{s}}
$$

Keterangan:

$\mathrm{N}_{\mathrm{i}}=$ kelimpahan plankton jenis ke-i (individu/liter)

$\mathrm{n}_{\mathrm{i}}=$ jumlah total individu plankton jenis ke-i

$\mathrm{Vr}=$ volume air contoh hasil saringan dalam botol sampel (ml)

$V_{0}=$ volume air contoh hasil saringan dalam Strip-SRC (ml)

Vs = volume air yang disaring oleh plankton-net (Iiter)

Setelah didapatkan kelimpahan masing-masing jenis plankton, dilakukan analisa terhadap struktur komunitasnya, yang meliputi: keanekaragaman jenis, keseragaman jenis, dan dominansi jenis (Odum, 1997 dan Basmi, 2000).

\section{Keanekaragaman Jenis}

Keanekaragaman jenis dihitung dengan menghitung Indeks Keanekaragaman Jenis Shannon - Wienner (H'). Rumusnya adalah sebagai berikut:

$$
H^{\prime}=\sum\left(\frac{n_{i}}{N} \bullet \ln \frac{n_{i}}{N}\right)
$$

Keterangan:

$\mathrm{H}^{\prime}=$ indeks keanekaragaman Shannon - Wienner

ni $=$ kelimpahan plankton jenis ke-i (individu/liter)

$\mathrm{N}=$ kelimpahan total plankton dari seluruh jenis (individu/liter)

$\ln =$ logaritma natural

Kisaran nilai:

$0 \leq \mathrm{H}^{\prime}<1 \quad$ tingkat keanekaragaman jenis rendah

$1 \leq \mathrm{H}^{\prime}<3 \quad$ tingkat keanekaragaman jenis sedang

$\mathrm{H}^{\prime} \geq 3$ tingkat keanekaragaman jenis tinggi 
Keseragaman Jenis

Keseragaman jenis dihitung dengan menghitung Indeks Keseragaman Jenis Evenness (E). Rumusnya adalah sebagai berikut:

$$
E=\frac{H^{\prime}}{\ln S}
$$

Keterangan:

$\mathrm{E}=$ indeks keseragaman Evenness

$\mathrm{H}^{\prime}$ = indeks keanekaragaman Shannon - Wienner

$\ln =$ logaritma natural

$\mathrm{S}=$ jumlah species plankton

Kisaran nilai:

$0 \leq \mathrm{E}<0.3$ tingkat keseragaman jenis rendah

$0.3 \leq \mathrm{E}<0.6$ tingkat keseragaman jenis sedang

$0.6 \leq \mathrm{E} \leq 1.0 \quad$ tingkat keseragaman jenis tinggi

Dominansi Jenis

Dominansi jenis dihitung dengan menghitung Indeks Dominansi Simpson. Rumusnya adalah sebagai berikut:

$$
D=\sum\left(\frac{n_{i}}{N}\right)^{2}
$$

Keterangan:

$\mathrm{D}=$ indeks dominansi simpson

$\mathrm{n}_{\mathrm{i}}=$ kelimpahan plankton jenis ke-i

$\mathrm{N}=$ kelimpahan total keseluruhan jenis plankton

Kisaran nilai:

$0 \leq \mathrm{D}<0.3 \quad$ tingkat dominansi jenis rendah

$0.3 \leq \mathrm{D}<0.6$ tingkat dominansi jenis sedang

$0.6 \leq \mathrm{D} \leq 1.0 \quad$ tingkat dominansi jenis tinggi

Dari hasil perhitungan nilai Indeks H' kita bisa menduga derajat pencemaran perairan. Klasifikasi derajat pencemaran perairan berdasarkan Indeks H' adalah sebagai berikut (Lee et al., 1978 dalam Fachrul, 2012):

$\mathrm{H}^{\prime} \geq 2.0 \quad$ belum tercemar

$1.6 \leq \mathrm{H}^{\prime}<2.0$ tercemar ringan

$1.0 \leq \mathrm{H}^{\prime}<1.6$ tercemar sedang

$1.0<\mathrm{H}^{\prime} \quad$ tercemar berat

\section{HASIL DAN PEMBAHASAN}


Pada Tabel 1. di bawah ini disajikan kelimpahan jenis fitoplankton pada masing-masing stasiun di bulan Januari 2018 dan 2019. Pada Januari 2018 di Stasiun 1 ditemukan 17 taksa, di Stasiun 2 ditemukan 7 taksa, dan di Stasiun 3 ditemukan 6 taksa, dimana kelimpahan total fitoplankton di Stasiun 1 adalah 240,948 sel $/ \mathrm{m}^{3}$, di Stasiun 2 adalah 202,979 sel $/ \mathrm{m}^{3}$, dan di Stasiun 3 adalah 129,077 sel/m². Pada Januari 2019, jumlah taksa dan kelimpahan total pada masing-masing stasiun lebih besar dari pada Januari 2018 dimana, jumlah taksa di Stasiun 1 adalah 24, di Stasiun 2 adalah 25, dan di Stasiun 3 adalah 24. Sedangkan kelimpahan total fitoplankton di Stasiun 1 adalah 848,118 sel $/ \mathrm{m}^{3}$, di Stasiun 2 adalah 2,594,201 sel $/ \mathrm{m}^{3}$, dan di Stasiun 3 adalah 2,195,654 sel/ $/ \mathrm{m}^{3}$. Kelimpahan fitoplankton di suatu perairan biasanya dipengaruhi oleh intensitas cahaya, kecerahan, dan keberadaan nutrien (ammonia, phosphat, dan nitrat). Kelimpahan fitoplankton dapat berfluktuasi, antara lain dipengaruhi oleh faktorfaktor tersebut.

Tabel 1. Kelimpahan Jenis dan Struktur Komunitas Fitoplankton pada Januari 2018 dan Januari 2019

\begin{tabular}{|c|c|c|c|c|c|c|}
\hline \multirow{3}{*}{ Jenis Fitoplankton } & \multicolumn{6}{|c|}{ Kelimpahan Fitoplankton $\left(\mathrm{Sel} / \mathrm{m}^{3}\right)$ di Stasiun } \\
\hline & \multicolumn{2}{|c|}{1} & \multicolumn{2}{|c|}{2} & \multicolumn{2}{|c|}{3} \\
\hline & 2018 & 2019 & 2018 & 2019 & 2018 & 2019 \\
\hline \multicolumn{7}{|l|}{ CYANOPHYCEAE } \\
\hline Trichodesmium sp. & 113,097 & 140,000 & 102,766 & 0 & 56,548 & 0 \\
\hline \multicolumn{7}{|c|}{ BACILLARIOPHYCEAE } \\
\hline Actinocyclus sp. & 0 & 0 & 0 & 2,899 & 0 & 10,870 \\
\hline Amphora sp. & 0 & 0 & 0 & 5,797 & 0 & 2,174 \\
\hline Biddulphia sp. & 14,137 & 4,058 & 1,277 & 11,594 & 0 & 97,826 \\
\hline Bacteriastrum sp. & 0 & 12,174 & 0 & 43,478 & 0 & 100,000 \\
\hline Biddulphia sp. & 0 & 14,203 & 0 & 78,261 & 0 & 52,174 \\
\hline Campylodiscus sp. & 615 & 4,058 & 0 & 17,391 & 0 & 4,348 \\
\hline Chaetoceros sp. & 0 & 18,261 & 638 & 55,072 & 0 & 95,652 \\
\hline Climacodium sp. & 0 & 6,087 & 0 & 0 & 0 & 8,696 \\
\hline Coscinodiscus sp. & 0 & 361,159 & 0 & $1,759,420$ & 0 & $1,321,739$ \\
\hline Cyclotella sp. & 0 & 36,522 & 0 & 113,043 & 0 & 0 \\
\hline Corethron sp. & 615 & 0 & 0 & 0 & 0 & 0 \\
\hline Coscinodiscus sp. & 38,109 & 0 & 81,064 & 0 & 60,236 & 0 \\
\hline Diploneis sp. & 0 & 4,058 & 0 & 5,797 & 0 & 2,174 \\
\hline Ditylum sp. & 5,532 & 0 & 0 & 11,594 & 0 & 6,522 \\
\hline Eucampia sp. & 4,303 & 0 & 0 & 0 & 0 & 2,174 \\
\hline Fragilaria sp. & 0 & 20,290 & 0 & 37,681 & 0 & 0 \\
\hline Guinardia sp. & 1,844 & 0 & 0 & 0 & 0 & 8,696 \\
\hline Gyrosigma sp. & 615 & 0 & 0 & 0 & 0 & 0 \\
\hline Hemiaulus sp. & 0 & 6,087 & 0 & 55,072 & 0 & 23,913 \\
\hline Lauderia sp. & 0 & 4,058 & 3,830 & 2,899 & 0 & 0 \\
\hline Melosira sp. & 0 & 0 & 0 & 11,594 & 0 & 0 \\
\hline Navicula sp. & 12,908 & 32,464 & 0 & 26,087 & 1,229 & 50,000 \\
\hline
\end{tabular}


DOI: 10.33373/sim-bio.v8i2.2042

\begin{tabular}{|c|c|c|c|c|c|c|}
\hline \multirow{3}{*}{ Jenis Fitoplankton } & \multicolumn{6}{|c|}{ Kelimpahan Fitoplankton $\left(\mathrm{Sel} / \mathrm{m}^{3}\right)$ di Stasiun } \\
\hline & \multicolumn{2}{|c|}{1} & \multicolumn{2}{|c|}{2} & \multicolumn{2}{|c|}{3} \\
\hline & 2018 & 2019 & 2018 & 2019 & 2018 & 2019 \\
\hline Nitzschia sp. & 9,835 & 20,290 & 2,553 & 34,783 & 1,844 & 56,522 \\
\hline Pinnularia sp. & 0 & 2,029 & 0 & 2,899 & 0 & 2,174 \\
\hline Pleurosigma sp. & 13,522 & 50,725 & 0 & 124,638 & 1,844 & 93,478 \\
\hline Rhizosolenia sp. & 4,303 & 32,464 & 0 & 107,246 & 0 & 69,565 \\
\hline Surirella sp. & & 2,029 & & 0 & & 6,522 \\
\hline Thalassionema sp. & 7,376 & 38,551 & 0 & 0 & 0 & 0 \\
\hline Thalassiosira sp. & 0 & 0 & 0 & 23,188 & & 71,739 \\
\hline Thalassiothrix sp. & 4,917 & 22,319 & 10,851 & 23,188 & 7,376 & 69,565 \\
\hline Triceratium sp. & 4,303 & 12,174 & 0 & 31,884 & 0 & 32,609 \\
\hline \multicolumn{7}{|l|}{ DINOPHYCEAE } \\
\hline Ceratium sp. & 4,917 & 2,029 & 0 & 2,899 & 0 & 6,522 \\
\hline Dinophysis sp. & 0 & 2,029 & 0 & 0 & 0 & 0 \\
\hline \multicolumn{7}{|l|}{ CHRYSOPHYCEAE } \\
\hline Dictyocha sp. & 0 & 0 & 0 & 5,797 & 0 & 0 \\
\hline Jumlah Taksa & 17 & 24 & 7 & 25 & 6 & 24 \\
\hline Kelimpahan (sel/m³) & 240,948 & 848,118 & 202,979 & $2,594,201$ & 129,077 & $2,195,654$ \\
\hline Indeks Keanekaragaman & 1.91 & 2.13 & 1.05 & 1.50 & 1.05 & 1.73 \\
\hline Indeks Keseragaman & 0.68 & 0.67 & 0.54 & 0.46 & 0.58 & 0.54 \\
\hline Indeks Dominansi & 0.26 & 0.22 & 0.42 & 0.47 & 0.41 & 0.38 \\
\hline
\end{tabular}

Komposisi Total Fitoplankton di Ketiga Stasiun pada 2019

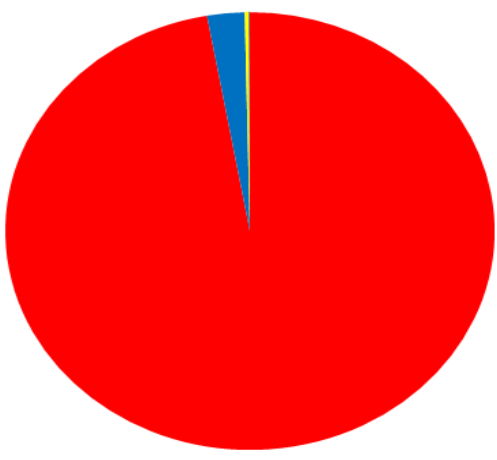

- BACILLARIOPHYCEAE

- CYANOPHYCEAE

DINOPHYCEAE

- CHRYSOPHYCEAE

Gambar 1. Perbandingan Komposisi Fitoplankton pada Tahun 2018 dan Tahun 2019

Pada Gambar 1 di atas dapat dilihat perbandingan komposisi fitoplankton di tahun 2018 dan tahun 2019. Di kedua tahun tersebut, komposisi fitoplankton didominasi oleh jenis-jenis dari kelas Bacillariophyceae. Menurut Nybakken (1992), fitoplankton berukuran besar yang tertangkap oleh jaring plankton terdiri dari dua kelompok besar, yaitu Diatom (Bacillariophyceae) dan Dinoflagellata. Diatom adalah komponen utama dalam komunitas plankton, yang mana kehidupan laut tergantung padanya (Nontji, 2008). Mendominasinya 
jenis-jenis fitoplankton dari kelompok Bacillariophyceae merupakan salah satu tanda baiknya produktivitas perairan.

Pada Tabel 2 di bawah ini disajikan kelimpahan jenis zooplankton pada masing-masing stasiun di bulan Januari 2018, dan Januari 2019. Pada Januari 2018 di Stasiun 1 ditemukan 6 taksa, di Stasiun 2 ditemukan 9 taksa, dan di Stasiun 3 ditemukan 9 taksa dimana, kelimpahan total zooplankton di Stasiun 1 adalah 16,998 individu/m³ ${ }^{3}$, di Stasiun 2 adalah 26,871 individu $/ \mathrm{m}^{3}$, dan di Stasiun 3 adalah 32,581 individu $/ \mathrm{m}^{3}$.

Tabel 2. Kelimpahan Jenis dan Struktur Komunitas Zooplankton pada Januari 2018 dan Januari 2019

\begin{tabular}{|c|c|c|c|c|c|c|}
\hline \multirow{3}{*}{ Jenis Zooplankton } & \multicolumn{6}{|c|}{ Kelimpahan Zooplankton (ind $/ \mathrm{m}^{3}$ ) di Stasiun } \\
\hline & \multicolumn{2}{|c|}{1} & \multicolumn{2}{|c|}{2} & \multicolumn{2}{|c|}{3} \\
\hline & 2018 & 2019 & 2018 & 2019 & 2018 & 2019 \\
\hline \multicolumn{7}{|l|}{ PROTOZOA } \\
\hline Amphorella sp. & 94 & 27,391 & 98 & 26,087 & 94 & 32,609 \\
\hline Codonellopsis sp. & 850 & 0 & 294 & 0 & 472 & 6,522 \\
\hline Rhabdonella sp. & 94 & 3,043 & 196 & 0 & 0 & 0 \\
\hline Tintinnopsis sp. & 7,366 & 0 & 18,830 & 0 & 20,682 & 0 \\
\hline \multicolumn{7}{|l|}{ CRUSTACEAE } \\
\hline Nauplius (stadia) & 8,216 & 30,435 & 1,961 & 30,435 & 8,594 & 48,913 \\
\hline Acartia sp. & 0 & 0 & 0 & 0 & 189 & 6,522 \\
\hline Microsetella sp. & 0 & 3,043 & 1,275 & 0 & 472 & 0 \\
\hline Oithona sp. & 378 & 18,261 & 2,550 & 13,043 & 1,228 & 22,826 \\
\hline Paracalanus sp. & 0 & 0 & 490 & 4,348 & 756 & 6,522 \\
\hline \multicolumn{7}{|l|}{ GASTROPODA } \\
\hline Larva Gastropoda (sp1) & 0 & 3,043 & 0 & 0 & 0 & 0 \\
\hline \multicolumn{7}{|l|}{ PELECYPODA } \\
\hline Larva Pelecypoda (sp1) & 0 & 6,087 & 1,177 & 0 & 0 & 9,783 \\
\hline \multicolumn{7}{|l|}{ POLYCHAETA } \\
\hline Larva Polychaeta (sp1) & 0 & 0 & 0 & 4,348 & 94 & 0 \\
\hline Jumlah Taksa & 6 & 7 & 9 & 5 & 9 & 7 \\
\hline Kelimpahan (ind $/ \mathbf{m}^{3}$ ) & 16,998 & 91,303 & 26,871 & 78,261 & 32,581 & 133,697 \\
\hline Indeks Keanekaragaman & 1.01 & 1.57 & 1.12 & 1.35 & 1.04 & 1.65 \\
\hline Indeks Keseragaman & 0.56 & 0.81 & 0.51 & 0.84 & 0.47 & 0.85 \\
\hline Indeks Dominansi & 0.42 & 0.25 & 0.51 & 0.30 & 0.47 & 0.23 \\
\hline
\end{tabular}

Pada Januari 2019, jumlah taksa yang ditemukan tidak terlalu berbeda jauh dengan tahun 2018. Namun kelimpahan total di masing-masing stasiun lebih besar daripada Januari 2018. Jumlah taksa di Stasiun 1 adalah 7, di Stasiun 2 adalah 5, dan di Stasiun 3 adalah 7. Kelimpahan total zooplankton di Stasiun 1 adalah 91,303 sel/ $\mathrm{m}^{3}$, di Stasiun 2 adalah 78,261 $\mathrm{sel} / \mathrm{m}^{3}$, dan di Stasiun 3 adalah 133,697 sel $/ \mathrm{m}^{3}$. Kelimpahan zooplankton antara lain dipengaruhi oleh kelimpahan fitoplankton, hal ini karena zooplankton adalah konsumer 
primer dari fitoplankton. Lebih besarnya kelimpahan zooplankton pada tahun 2019 dapat dipahami karena kelimpahan fitoplankton di tahun 2019 pun lebih besar daripada tahun 2018 .

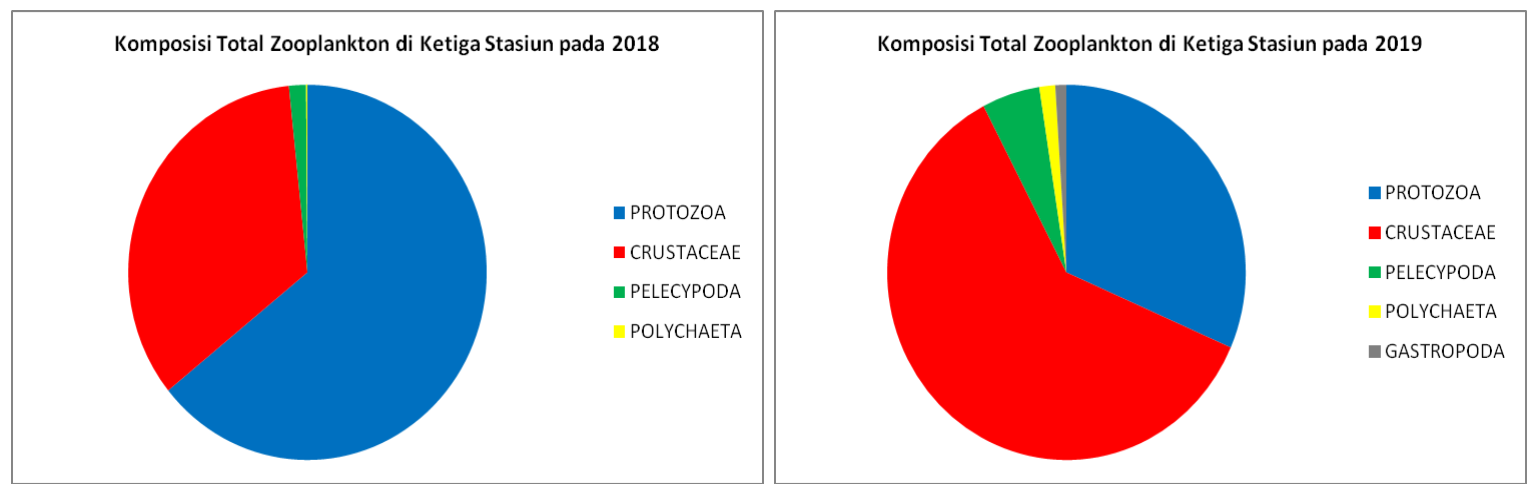

Gambar 2. Perbandingan Komposisi Zooplankton pada Tahun 2018 dan Tahun 2019

Pada Gambar 2 di atas dapat dilihat perbandingan komposisi zooplankton di tahun 2018 dan tahun 2019. Pada tahun 2018 ditemukan 4 kelompok zooplankton, yaitu protozoa, crustacean, pelecypoda, dan polychaeta. Pada tahun 2019 ditemukan 5 kelompok zooplankton, yaitu protozoa, crustacean, pelecypoda, polychaeta, dan gastropoda. Di tahun 2018, zooplankton didominasi oleh jenis-jenis protozoa; sedangkan di tahun 2019 didominasi oleh jenis-jenis crustacea.

Pada Tabel 2 dapat dilihat bahwa zooplankton yang paling banyak ditemukan pada sampel yang diambil di Januari 2018 adalah Tintinnopsis sp; jenis tersebut banyak ditemukan pada sampel yang diambil di Januari 2019. Menurut Nontji (2008), protozoa mempunyai kenanekaragaman jenis yang sangat tinggi, tetapi yang hidup di laut sebagai plankton umumnya dapat digolongkan dalam kelas Ciliata dan Sarcodina. Salah satu ordo terpenting di bawah Ciliata adalah Tintinnida.

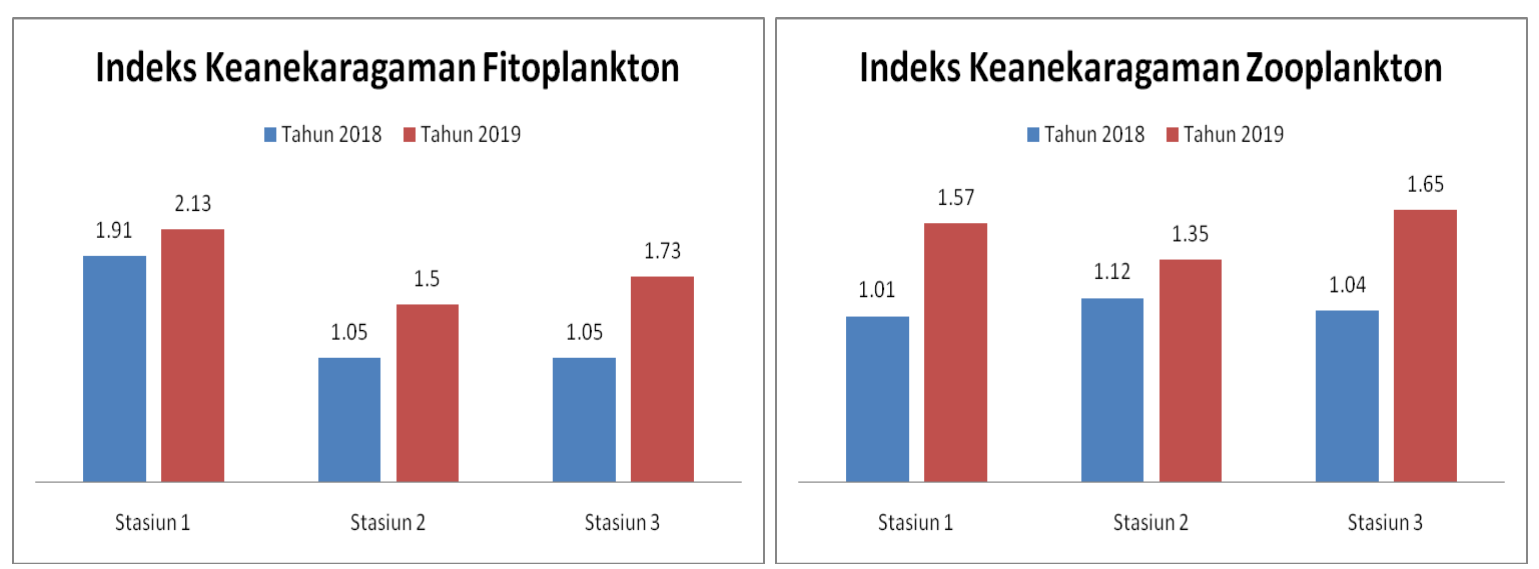

Gambar 3. Indeks Keanekaragaman Jenis Fitoplankton \& Zooplankton Tahun 2018 dan 2019 
SIMBIOSA Vol 8 (2): 122-135, Desember 2019

DOI: 10.33373/sim-bio.v8i2.2042

Lani Puspita, 2019. Plankton Community Structure in the Belat Strait

Pada Gambar 3. disajikan Indeks Keanekaragaman Jenis Shannon-Wienner (H') fitoplankton dan zooplankton pada masing-masing stasiun di tahun 2018 dan 2019. Pada gambar tersebut dapat dilihat bahwa keanekaragaman jenis fitoplankton dan zooplankton tergolong "sedang", karena nilainya berkisar antara 1 dan 3. Apabila suatu perairan memiliki tingkat keanekaragaman jenis "sedang” atau nilai $H$ ' antara 1 sampai 3, maka kondisi komunitas mudah berubah dengan mengalami pengaruh lingkungan relatif kecil. Sedangkan apabila suatu perairan memiliki tingkat keanekaragaman jenis "tinggi" atau nilai H' lebih besar dari 3, maka dapat diketahui bahwa kondisi lingkungan dalam kondisi prima (Odum, 1998 dan Basmi 2000). Dengan kondisi keanekaragaman jenis yang termasuk dalam kategori “sedang”, maka dapat dikatakan bahwa komunitas plankton di ketiga lokasi ini mudah berubah. Keanekaragaman plankton di ketiga lokasi sampling dapat berubah menjadi rendah apabila ada bahan pencemar masuk, ataupun menjadi tinggi apabila kondisi lingkungannya optimal. Menurut Nontji (2008), distribusi plankton bervariasi secara temporal (bergantung waktu) dan spasial (menurut ruang), yang banyak ditentukan oleh factor-faktor lingkungan yang mempengaruhinya. Sebaran horizontal banyak ditentukan factor suhu, salinitas, dan arus; keberadaan unsur hara dan cahaya juga mempengaruhi keberadaan plankton (khususnya fitoplankton).

Menurut Lee et al., 1978 dalam Fachrul, 2012, perairan dengan Indeks H'> 2.0 menandakan perairan yang belum tercemar, nilai $1.6 \leq \mathrm{H}^{\prime}<2.0$ menandakan perairan yang tercemar ringan, dan nilai $1.0 \leq \mathrm{H}^{\prime}<1.6$ menandakan perairan yang tercemar sedang. Gambar 3 menunjukan bahwa nilai Indeks H' pada tahun 2019 lebih baik daripada tahun 2018. Pada tahun 2018, keanekaragaman jenis plankton mengindikasikan perairan yang tercemar sedang hingga ringan; sedangkan pada tahun 2019, keanekaragaman jenis plankton mengindikasikan perairan yang tercemar sedang hingga belum tercemar.

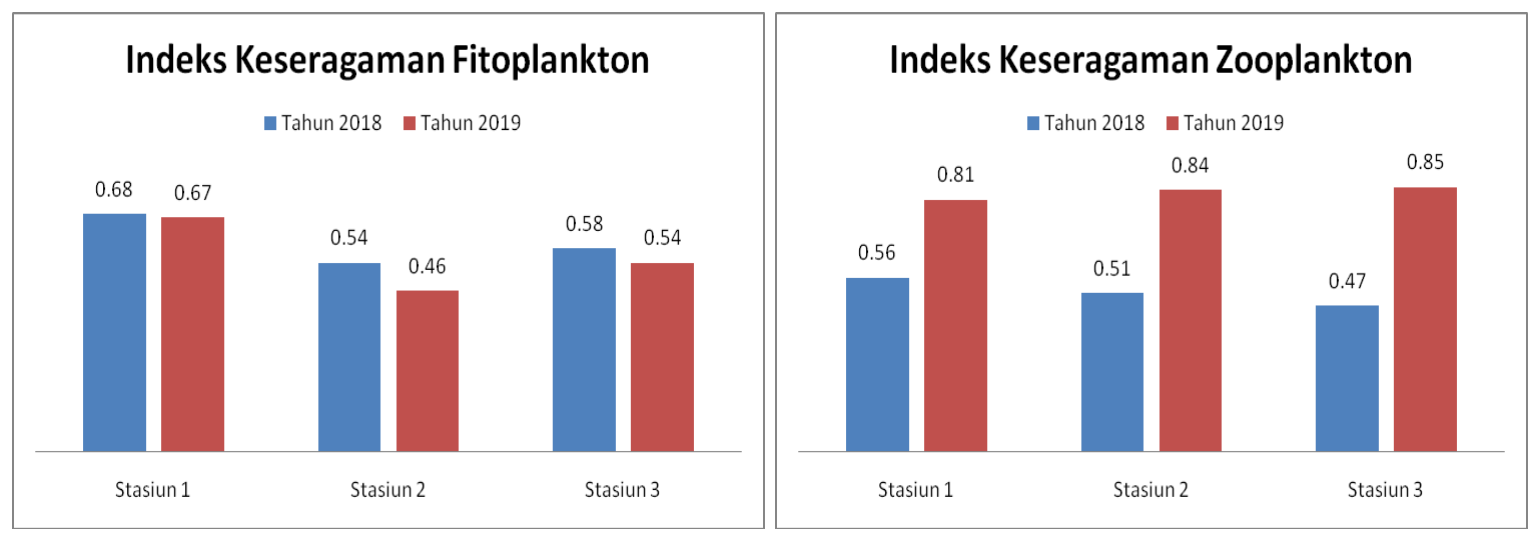

Gambar 4. Indeks Keseragaman Jenis Fitoplankton \& Zooplankton Tahun 2018 dan 2019 


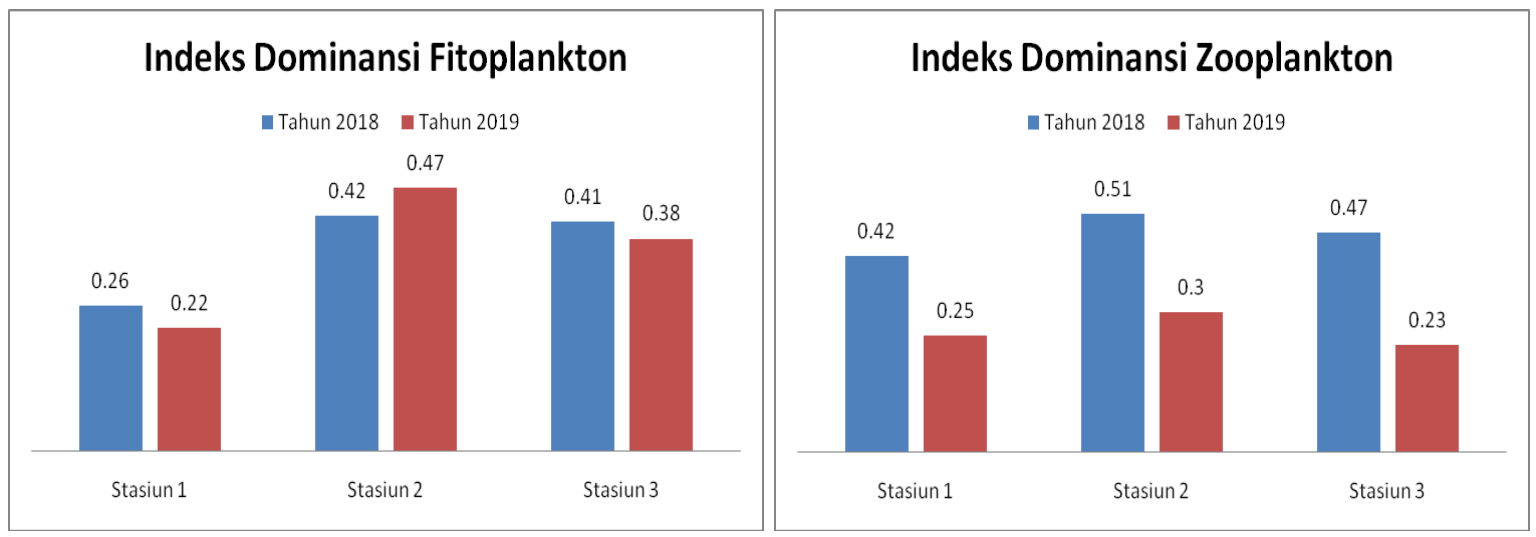

Gambar 5. Indeks Dominansi Jenis Fitoplankton \& Zooplankton Tahun 2018 dan 2019

Pada Gambar 4 disajikan Indeks Keseragaman Jenis fitoplankton dan zooplankton pada setiap stasiun di tahun 2018 dan 2019. Pada Gambar 5 disajikan data untuk Indeks Dominansi Jenis-nya. Indeks Keseragaman dan Indeks Dominansi menunjukan nilai yang berbanding terbalik, apabila nilai Indeks Keseragaman tinggi maka nilai Indeks Dominansi rendah, dan demikian sebaliknya. Indeks Keseragaman Jenis mengambarkan kondisi habitat relatif serasi (baik) untuk pertumbuhan dan perkembangan masing-masing spesies. Nilai Indeks Keseragaman jenis berkisar antara $0 \leq \mathrm{E}<0,3$ berarti keseragaman antar spesies di dalam komunitas adalah "rendah", mencerminkan keseragaman yang dimiliki masing-masing spesies sangat jauh berbeda. Bila nilai Indeks Keseragaman Jenis berkisar antara 0,3 $\leq \mathrm{E}<0,6$ berarti keseragaman antar spesies di dalam komunitas "sedang", mencerminkan keseragaman yang dimiliki masing-masing tidak jauh berbeda, tidak menunjukan perbedaan yang sangat mencolok. Bila nilai Indeks Keseragaman Jenis berkisar antara $0,6 \leq \mathrm{E} \leq 1$, maka keseragaman antar spesies dapat dikatakan relatif merata dan hal tersebut menunjukan kondisi yang baik ( Odum, 1998 dan Basmi 2000).

Bagi Indeks Dominansi, hal yang berlaku adalah kebalikan dari Indeks Keseragaman. Apabila Indeks Dominasi Jenis "rendah" atau nilai berkisar antara $0 \leq \mathrm{D}<0,3$, maka di dalam komunitas yang sedang diamati tidak terdapat spesies yang secara ekstrim mendominasi spesies lainnya, hal ini menunjukan kondisi komunitas dalam keadaan stabil dan kondisi lingkungan prima. Apabila nilai Indeks Dominasi Jenis "sedang” atau nilai indeks berkisar antara $0,3 \leq \mathrm{D}<0,6$, berarti di dalam komunitas tidak ada spesies yang mendominasi secara nyata terhadap spesies lainya. Sedangkan apabila nilai Indeks Dominasi Jenis berkisar antara $0,6 \leq \mathrm{D}<1$, berarti di dalam Komunitas dijumpai spesies yang mendominasi spesies 
lainya yang mencerminkan kondisi komunitas dalam keadaan labil, hal ini menyebabkan habitat yang dihuni sedang mengalami ganguan (Odum, 1998 dan Basmi, 2000).

Pada Gambar 4 dapat dilihat bahwa Indeks Keseragaman Jenis fitoplankton di Januari 2018 dan Januari 2019 tergolong sedang hingga tinggi; sedangkan untuk zooplankton, Indeks Keseragaman Jenis di Januari 2018 seluruhnya tergolong sedang dan di Januari 2019 seluruhnya tergolong tinggi. Hal yang sebaliknya terjadi untuk Indeks Dominansi Jenis; Indeks Dominansi Jenis fitoplankton untuk Januari 2018 dan Januari 2019 tergolong rendah hingga sedang; sedangkan untuk zooplankton, Indeks Dominansi Jenis di Januari 2018 seluruhnya tergolong sedang dan di Januari 2019 seluruhnya tergolong rendah. Hal ini menunjukan tidak ada spesies yang mendominasi secara nyata terhadap spesies lain dan kondisi yang relatif baik.

Tabel 3. Hasil Analisis Kualitas Air Selat Belat

\begin{tabular}{lccccccc}
\hline & & \multicolumn{7}{c}{ Hasil Pengukuran Di Stasiun } \\
\cline { 3 - 8 } \multicolumn{1}{c}{ Parameter } & Satuan & \multicolumn{7}{c}{$\mathbf{1}$} & $\mathbf{2}$ & \multicolumn{3}{c}{$\mathbf{3}$} \\
\cline { 3 - 8 } & & $\mathbf{2 0 1 8}$ & $\mathbf{2 0 1 9}$ & $\mathbf{2 0 1 8}$ & $\mathbf{2 0 1 9}$ & $\mathbf{2 0 1 8}$ & $\mathbf{2 0 1 9}$ \\
\hline Kekeruhan & $\mathrm{NTU}$ & 17 & 1 & 28 & 1 & 24 & 1 \\
TSS & $\mathrm{mg} / \mathrm{l}$ & 28 & 16 & 26 & 7 & 31 & 11 \\
Suhu & ${ }^{\circ} \mathrm{C}$ & 29.9 & 30.3 & 30.3 & 30.5 & 30.1 & 30.1 \\
pH & & 7.79 & 7.60 & 7.72 & 7.63 & 7.83 & 7.54 \\
Salinitas & $\%$ & 29.0 & 30.00 & 29.0 & 30.00 & 29.0 & 30.00 \\
\hline
\end{tabular}

Tabel 3. di atas menyajikan beberapa parameter kualitas air di lokasi penelitian pada saat pengambilan sampel plankton. Menurut Nontji (2008), suhu, salinitas, dan cahaya banyak menentukan kelimpahan dan distribusi plankton. Intensitas cahaya di perairan antara lain dipengaruhi oleh kekeruhan dan Total Suspended Solids (TSS).

Suhu dapat mempengaruhi fotosintesis di laut, baik secara langsung maupun tidak langsung. Pengaruh langsung karena reaksi kimia enzimatik yang berperan dalam proses fotosintesis dikendalikan oleh suhu. Peningkatan suhu sampai batas tertentu akan menaikkan laju fotosintesis. Pengaruh tidak langsung adalah karena suhu akan menentukan struktur hidrologis suatu perairan tempat fitoplankton itu berada. Suhu akan sangat menentukan berat jenis air (Nontji, 2008). Selain dipengaruhi oleh suhu, reaksi kimia enzimatik juga dipengaruhi oleh pH (Kimball, 1996). Mengacu pada Baku Mutu Air Laut untuk Biota Laut pada Keputusan Menteri LH No. 51 Tahun 2004 Lampiran 3, baku mutu suhu untuk perairan mangrove adalah $28-32^{\circ} \mathrm{C}$ dan baku mutu pH adalah 7 - 8.5 (Kementerian Lingkungan Hidup, 2004). Berdasarkan baku mutu tersebut, dapat kita simpulkan bahwa kondisi suhu dan pH di lokasi penelitian masih memenuhi baku mutu yang berlaku. 
Baku mutu kekeruhan pada air laut untuk biota laut adalah 5 NTU (Kementerian Lingkungan Hidup, 2004); data pada Tabel 5 menunjukan bahwa kekeruhan di Januari 2018 berkisar antara 17 s.d 28 NTU, sedangkan untuk Januari 2019 adalah 1 NTU. Kondisi tersebut menunjukan bahwa kekeruhan di Januari 2018 tidak memenuhi baku mutu yang ditetapkan, namun kekeruhan di Januari 2019 masih memenuhi baku mutu. Kekeruhan menggambarkan sifat optik air yang ditentukan berdasarkan banyaknya cahaya yang diserap dan dipancarkan oleh bahan-bahan yang terdapat dalam air. Kekeruhan dapat disebabkan oleh mikroorganisme atau detritus organik; silika atau mineral lainnya termasuk $\mathrm{Zn}, \mathrm{Fe}$, dan $\mathrm{Mn}$; serta debu, pasir, dan tanah liat baik yang berasal dari proses alami maupun yang berasal dari kegiatan domestik dan industri (Bhattacharya, 1992). Kekeruhan terutama disebabkan oleh erosi tanah di DAS maupun di saluran/sungai. Air sungai biasanya menjadi lebih keruh pada saat terjadi hujan lebat dibandingkan pada kondisi normal (Suripin, 2002). Kondisi kekeruhan yang jauh lebih baik di Januari 2019 selaras dengan hasil kelimpahan dan keanekaragaman jenis plankton yang lebih tinggi di Januari 2019.

Baku mutu TSS pada air laut untuk biota laut di ekosistem mangrove adalah $80 \mathrm{mg} / \mathrm{l}$ (Kementerian Lingkungan Hidup, 2004); data pada Tabel 5 menunjukan bahwa konsentrasi TSS di Januari 2018 dan Januari 2019 masih memenuhi baku mutu yang ditetapkan. Konsentrasi TSS di Januari 2019 lebih rendah daripada Januari 2018, hal ini selaras dengan nilai kekeruhannya. Total Suspended Solid (TSS) adalah bahan-bahan tersuspensi yang

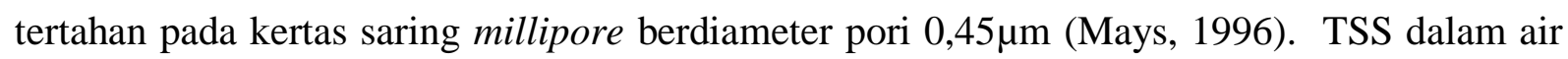
umumnya terdiri dari fitoplankton, zooplankton, kotoran manusia, kotoran hewan, lumpur, sisa tanaman dan hewan, serta limbah industri. Erosi tanah akibat hujan lebat dapat mengakibatkan naiknya nilai TSS secara mendadak (Sastrawijaya, 2000).

\section{KESIMPULAN}

Berdasarkan hasil analisis didapatkan bahwa Indeks $\mathrm{H}$, E, dan D dari sampel fitoplankton yang diambil pada 8 Januari 2018 secara berturut-turut berkisar antara: 1.05 1.91, 0.54 - 0.68, dan 0.26 - 0.42; sedangkan untuk sampel zooplankton nilai indeks secara berturut-turut berkisar antara: 1.01 - 1.12, 0.47 - 0.56, dan 0.42 - 0.51. Dan nilai Indeks H, E, dan D dari sampel fitoplankton yang diambil pada 30 Januari 2019 secara berturut-turut berkisar antara: 1.50 - 2.13, 0.46 - 0.67, dan 0.22 - 0.47; sedangkan untuk sampel zooplankton 
nilai indeks secara berturut-turut berkisar antara: 1.35 - 1.65, 0.81- 0.85, dan $0.23-0.30$. Nilai Indeks $\mathrm{H}$ yang berkisar antara 1.01 - 2.13 menunjukan bahwa kondisi perairan berada pada kondisi tercemar sedang, tercemar ringan, dan belum tercemar. Nilai Indeks E yang berkisar antara 0.46 - 0.85, serta nilai Indeks D yang berkisar antara 0.22 - 0.51 menunjukan bahwa tidak ada spesies yang mendominasi secara nyata terhadap spesies lain dan kondisi yang relatif baik.

Kelimpahan fitoplankton dan zooplankton pada sampel yang diambil di Januari 2019 lebih tinggi daripada sampel yang diambil di Januari 2018. Pada sampel 8 Januari 2018, fitoplankton didominasi oleh jenis-jenis dari kelas Bacillariophyceae; sedangkan zooplankton didominasi oleh jenis-jenis dari filum Protozoa. Pada sampel 30 Januari 2019, fitoplankton didominasi oleh jenis-jenis dari kelas Bacillariophyceae; sedangkan zooplankton didominasi oleh jenis-jenis dari filum Crustacea. Lebih tingginya kelimpahan fitoplankton dan zooplankton pada Januari 2019 selaras dengan hasil pengukuran kekeruhan dan TSS yang lebih baik pada Januari 2019 dibanding Januari 2018.

\section{REFERENSI}

Basmi, J. 2000. Planktonologi: Plankton sebagai Bioindikator Kualitas Perairan. Fakultas Perikanan dan Ilmu Kelautan. Institut Pertanian Bogor. Bogor.

Bhattacharya, S. K. 1992. Urban Domestic Water Supply in Developing Countries. CBS Publishers \& Distributors. New Delhi.

Fachrul, M. F. 2012. Metode Sampling Bioekologi. Bumi Aksara. Jakarta.

Kimbal, J.W. 1996. Biologi, Jilid 1, edisi kelima. Penerbit Erlangga. Jakarta.

Kementerian Lingkungan Hidup - RI, 2004. Keputusan Menteri Lingkungan Hidup Nomor 51 Tahun 2004 tentang Baku Mutu Air Laut. Kementerian Lingkungan Hidup - RI. Jakarta

Mays, L. W. 1996. Water Resources Handbook. McGraw-Hill. New York.

Nontji, A. 2008. Plankton Laut. LIPI Press. Jakarta.

Nybakken, J. W. 1992. Biologi Laut: Suatu Pendekatan Ekologis. PT. Gramedia Pustaka Utama. Jakarta.

Odum, E. P. 1998. Dasar-Dasar Ekologi. Gadjah Mada University Press. Jogjakarta.

Sastrawijaya, A. Tresna. 2000. Pencemaran Lingkungan. Penerbit Rineka Cipta. Jakarta.

Suripin. 2002. Pelestarian Sumberdaya Tanah dan Air. Penerbit ANDI. Yogyakarta.

Yamaji, I. 1979. Illustrations of the Marine Plankton of Japan. Hoikusha Publishing Co., Ltd. 